UDC 811.111'373.72

DOI https://doi.org/10.32841/2409-1154.2021.48-2.20

\author{
Cherniavska A. V., \\ Postgraduate Student at the Germanic Languages and Translation Studies Department \\ Drohobych Ivan Franko State Pedagogical University
}

\title{
SEMANTICS OF PHRASEOLOGICALLY OBJECTIVIZED FLORONYMS IN THE ENGLISH LANGUAGE
}

Summary. The article focuses on the semantics of the floronyms daisy, lotus, briar, primrose, furze, patience, lavender, pansy, wallflower and tulip in English phraseology. It has been determined, that the meaning of the analysed floronyms is characterized by a meliorative as well as pejorative colouring. A range of associations and symbolical as well as metaphoric meaning of the researched floronyms have been analysed. A variety of concepts, phraseologically verbalized due to the semantic constutuents of the researched floronyms, have been scrutinized.

It has been ascertained, that the floronym daisy is associated with spring, freshness, cleanliness, and its semantic components contribute to phraseological objectivation of the concepts happiness, death, commonness, difference, incongruity.

The analysed floronym lotus can symbolize tranquillity and be associated with drug addiction. Greek mythology serves a source for such associations of the floronym as: a daydreamer, daydreams, delight, laziness, carefree life. Two latter associations are inherent of the floronym primrose, which can serve as a standard of a yellow colour, symbolize youth and be associated with fragility, fading, death, way of pleasure, at the same time the components of its semantics contribute to phraseological objectivation of the concept incongruity and the cause and effect connection "idleness $\rightarrow$ decay."

The seme "beauty" is singled out as a dominant constituent in the floronym brier's semantic structure and the components causticity, problems, something unpleasant constitute several of its associations. The researched floronyms brier and furze have a dominant seme "pungency" and association with the cruelty of nature. The floronym furze has meliorative associations with kisses and love, its semantic components serve as a basis for proverbial objectivation of the universal binary oppositions "own - alien", "better - worse."

In the figurative meaning, the floronym lavender can be associated with freshness, storage, pawn, quarrel, prison, death, and it is characterized by the connotation of thrift and difficulty. The semantics of the analysed floronym has a connotation of homosexuality as well as the floronym pansy's, which can also be associated with weakness, effeminacy. The semantic components of the floronym wallflower serve as a basis for phraseological verbalization of the concept waiting, and floronym tulip - the concept tastelessness.

Key words: floronym, idiom, paroemia, symbolical meaning, seme, semantics, concept.

Problem statement. The floronyms daisy, lotus, briar, primrose, furze, lavender, pansy, wallflower and tulip are verbalized in English idioms and proverbs. The phraseologisms with the analysed floronyms have not been singled out in the Ukrainian language. There is a certain asymmetry in the flower names verbalization in the analysed languages. O. Levchenko testifies to similar findings, she states that there exists an interlingual asymmetry of the plant symbolism [1, p. 206].
The main objective of the article is to research the semantics of the floronyms that are inherent in English phraseology and are not represented in Ukrainian.

Findings and discussions. Obviously, phraseologisms are not only a part of a linguistic system, but also an important and expressive component within a cultural framework. So, "proverbs and sayings serve as a basis for manifestation of basic universal and / or idioethnic constants of lingual consciousness [2, p. 8]. The phraseological item $(\mathrm{PhI})$ daisy chain [3] denotes a garland of daisies that is worn around a neck or a wrist by the British children, and the researched floronym is used in the denotative meaning: "a small white flower with a yellow centre, usu growing wild" [4, p. 291]. This flower is also known as: oxeye daisy, white daisy, marguerite and English daisy [3]. A derivative poetical adjective daisied [5, p. 260] literally means "covered with daises."

A popular English belief embodied in the paroemias: it is not spring until you can plant your foot upon twelve daisies [6, p. 469; 7, p. 264]; When you can tread on nine daises at once, spring has come [8, p. 234] signifies that a real spring comes when there is such a multitude of daises that one's foot can trample on a variable number of them (twelve or nine) simultaneously. The analysed floronym is used in the direct meaning, associated with the spring, and has temporal characteristics.

The simile (as) fresh as a daisy [9, p. 359; 7, p. 400]; fresh as a daisy / May gowan (a Scottish variant of the flower's name) [10, p. 447] contains the floronym daisy in combination with the attribute fresh. The basic semantic components of the analysed floronym are "freshness, health, cheerfulness". Though the floronym serves as a variable element in this context, as there exist the variants of this phraseologism with other floronyms in the English language, such as: (as) fresh as a flower, as a rose [11, p. 523]. The researched floronym can be associated with cleanliness in the Scottish collective consciousness: clean as a gowan [10, p. 447]. A colloquial simile dink [neat, finely dressed] as a daisy [10, p. 447] can be used to denote a decent, neatly dressed person. The concept of something ordinary is verbalized in a stereotyped comparison (a term used in the taxonomy by A. Pamies-Bertran [12, p. 68]): common as daisies $[10$, p. 447]. Moreover, the components of the analysed floronym's semantics can serve as a basis for actualization of the concept happiness: happy as daisies in the sunshine [10, p. 447]. In the structure of the simile as like as a dock to a daisy [6, p. 193] the floronym dock is contrasted with the floronym under research. This stereotyped comparison has a pejorative connotation, and semantic components of the analysed floronym contribute to actualization of the concepts difference, incongruity. Consequently, the floronym daisy can be associated with cleanliness, decency, neatness, happiness and inappropriateness in the English and Scottish worldview. 
The adjective, derived from the analysed floronym, gowangobbit / gowany [10, p. 447] is used for the description of the day that begins as deceptively bright, but bursts into a storm afterwards. So, the floronym gowan can be associated with the unsteadiness of the weather.

In order to denote astonishment when something extremely unexpected happens, an emphatic interjection cow the gowan $[10$, p. 447$]$ is used. A euphemistic invective PhI with the analysed floronym not care / give / worth a gowan [10, p. 447] implies the low value of the gowan flower for the Scotsmen.

A humorous phraseological euphemism, which has a whole range of variants push up (the) daisies [11, p. 1086]; be pushing up (the) daisies [13, p. 78]; under the daisies [10, p. 645]; turn your toes up at the daisies $[10$, p. 645]; put the daisy-quilt over... [10, p. 753]; suck daisy roots [10, p. 645], means "to be dead". People created an oath warning: not till I'm looking up the daisy mores! [10, p. 645] which implies "never; over my dead body". A peremptory and authoritarian connotation is inherent in this PhI. Therefore, the analysed floronym can be associated with death. The same connotation is intrinsic in the floronym daisy's semantics within the historical idiom, known back to 1553: To leap at a daisy [6, p. 450], which literally means "to be hanged."

A range of terms with the analysed floronym, belonging to different areas of knowledge, function in the English language. In the domain of aviation, the phraseo-term [12, p. 67] daisy-clipping $[5, p .260]$ is used to signify a flight performed very close to the ground. Currently, the phraseo-term daisy chain [14] can denote a range of computers or other devices connected into a network, or software, that is consequently joined together in a linear series. Daisy chain [15] is also associated with a string of integrated people or objects. The onymic word-group [12, p. 67] daisy dukes / Daisy Dukes [15] is used in colloquial speech for the denotation of the shorts that cover only the hip, and were made from cutting short a pair of jeans.

English speakers use a jocular informal interjection: oopsa-daisy (whoops-a-daisy) [13, p. 78]; ups-a-daisy [11, p. 949]; Upsadaisy! / Upsee-daisy! / Upsy-daisy! [16, p. 434] in the common language as an encouragement for children when they fall down, and try to sit up or get up afterwards.

Researching slang meanings of the analysed floronym, it is necessary to mention that the floronym daisy can represent a clever, pretty and optimistic girl [17]; a person who is considered to be cool, prominent; or an excellent thing [3]. The phraseo-term daisycutter / Daisy Cutter (the BLU-82B) [17] functions in the area of American military slang for designating a powerful lethal bomb with a huge blast effect.

In the English common language, there has long existed a euphemistic idiom pluck dazies (1606) [6, p. 623] for the signification of a urination act, though the researched floronym serves as a variable element in the structure of the idiom, compare: Pick (pluck) a rose [6, p. 684].

The floronym lotus (which is also known as a water lily) has the following denotative meaning: "a tropical plant with white or pink flowers growing on the surface of lakes, etc." [4, p. 698]. In ancient Greek mythology it was considered that if a man eats a fruit of the plant lotus [11, p. 805], it will make him dreamy, forgetful and lazy. Hence, the following derivative phraseological compounds are noteworthy: lotus-eater [11, p. 805] denoting a daydreamer; a person who lives a lazy dreamy life and is not concerned with the business of the world (from the people in the Odyssey who behaved similarly after eating a fruit called a lotus); lotus-eating [5, p. 690] - daydreams; pleasant idleness; lotus-eating existence $[9$, p. 630$]-$ a leisurely, carefree life; respectively - lotus (-)land [9, p. 630; 5, p. 690] is a manifestation of the fairy land of abundance, idleness and pleasure. The idiom with the analysed floronym (to) eat lotus [9, p. 299] literally means "to do nothing, to idle". So, the floronym lotus explicates the semes "laziness, fantasies, carefree life" in these examples. An additional meaning of the compound lotus-eater [18, p. 291] is "a man who lives in a state of blissful oblivion and laziness which is caused by applying drug substances". Thus, the floronym under analysis can be associated with drug addiction.

The phraseologism lotus position [11, p. 805] signifies a position in Yoga used for meditation, in which a person sits on the floor with his legs crossed and his hands on his knees. A person in this position reminds a lotus-flower. The analysed floronym can be associated with the state of tranquillity in this context.

The floronym brier (variants a briar and wild rose), which has similarly undergone phraseological actualization in the English language, is defined as: "a prickly bush, especially wild rose bush" [4, p. 138]. The stereotyped simile fair as a wild rose [10, p. 444] combines the researched floronym and the attribute fair. The floronym wild rose contains an inherent seme "beauty", which serves as a dominant semantic constituent of nearly all the floronyms.

The analysed floronym can also be associated with a caustic / witty person in the English language, namely: rough / sharp as a briar [10, p. 444]. Evidently, due to the common feature of a flower and a person - pungency, a metaphoric transfer took place and the given stereotyped comparison was coined.

The idiom in the briars [10, p. 391] means "to have problems", whereas the capability to stand fast, to be resilient is phraseologically objectivised in the idiom: lay in the briars [10, p. 391]. The PhI stick in the briars $[10$, p. 391$]$ has the meaning "to get into trouble", and leave in the briars [10, p. 391] - "to involve somebody in problems". The association of the researched floronym with trouble is traced within the boundaries of the paroemia: it is good to nip the brier in the bud [10, p. 784], which means "to avert future troubles". Therefore, the analysed floronym in these contexts signifies hardships, problems.

The floronym briar's association with cruelty found its manifestation in the paroemia: the rose hides the briar [10, p. 444], which is inherent in the Irish linguoculture. The saying reveals the fact that good looks do not preclude a cruel nature, at the same time the floronym rose embodies the concept beauty, and floronym briar - cruelty [19, p. 27].

Proverbs butter's dear-bought when it's licked off a briar [Ire] $[10$, p. 330] and Don't lick the honey off a briar even if it is sweet [US] [20, p. 306] are used for the denotation of something which is hard to achieve. People created a derogatory, vulgar observation about a restless man: has a briar in the arse [10, p. 391]. The seme "pungency / causticity" of the floronym brier is a dominant in these contexts; moreover, the floronym serves as a manifestation of something unpleasant, which is standing in the way.

In American as well as in Canadian English, there exists a proverbial warning: He who goes barefooted shouldn't plant briars [20, p. 37], where the concepts of appropriateness, congruity are verbalized, and the researched floronym is associated with troubles. It is necessary to mention a symbolical meaning of the wild rose [3], since the flower serves as a floral emblem of the American state Iowa. 
The colour name primrose [4, p. 918]; primrose colour [21, p. 164] primrose yellow [15] signifies a pale yellow (lemon) colour and is derived from the same floronym primrose (variant a primula): "a wild plant that has pale yellow flowers in spring; one of these flowers" [4, p. 918]. The compound primrose green [15], representing a yellow colour with a tender greenish tint, can be referred to this category. The analysed floronym has also the variants cowslip / paigle, which can serve as the standards of a yellow colour that was reflected in the standard similes: As yellow as a paigle [6, p. 925] (1678); As blake (yellow) as a paigle (cowslip) [6, p. 889]. Moreover, there exists a range of similes with the constant semantic attribute yellow in combination with other floronyms in the English language, namely: yellow as a gowan / kingcup / globe flower [10, p. 448]; blake [yellow-gold-nEng] as (a) marigold(s) / Mary gold [10, p. 448]; yellow as a meadowbout / kingcup [10, p. 448]; yellow as the guilde / corn marigold $[10$, p. 448] [Sc]; yellow as a ragweed / ragwort [10, p. 448] [Ire]; which function in the speech of the people who inhabit Scotland, Ireland and Northern England.

The idiom with the scrutinised floronym (the) primrose path [22, p. 437; 23, p. 197] indicates "the way covered with flowers; the path of pleasure leading to disastrous consequences; the path of least resistance". In this instance, we trace the allusion to the Shakespearian proverbialized expression (the term coined by Z. Kotsiuba [2, p. 57]) the primrose (-) path of dalliance [9, p. 775; 10, p. 830] from the tragedy "Hamlet." Ophelia utters these words to Hamlet, meaning that the pursuit of pleasure leads to ruin. One more $\mathrm{PhI}$ serves as a logical continuation in the series: the primrose path (to ruin, destruction, etc.) [3]. Consequently, the floronym under research can be associated with an easy and pleasant life, enjoyment, idling, and decadence. Besides, the floronym primrose can serve as a symbol of youth / juvenility [3]. Similarly, in the proverbialized expression by J. Milton: $O$ Fairest flower, no sooner blown but blasted, Soft silken primrose fading timelessly (1637) [24], the analysed floronym is associated with fragility, fading and death.

There existed derogatory figurative comparisons with the researched floronym in the speech of the people from the Midlands: like a primrose in a casson [dried cow-turd] [10, p. 448]; fine as a cow-turd stuck with primroses! [10, p. 221]; fine as Forty Poke's wife who dressed herself with primroses [10, p. 799]. The PhIs depict an inappropriate piece of finery; or a plain lass in a fine bonnet. They can also serve as an ironic response to someone's outfit, implying that no matter how beautiful the embellishments are, they cannot conceal what is underneath. Therefore, the semantic components of the floronym under analysis contribute to the phraseological verbalisation of the concept incongruity.

The floronym buttercup is associated with freshness, which is implied by the simile: fresh as a buttercup [10, p. 447]. The floronym under analysis has a supplementary variant of the flower's name crow-flower. Moreover, the crow-flower / жовтеиь can serve as one of the prototypes of a yellow colour (that is evident from the Ukrainian name of the flower, which has not been phraseologically verbalized in the Ukrainian language), as it is both figuratively and directly objectivized in the simile: yellow as a crowflower [10, p. 447] and it is recorded in the English definition: " $a$ wild plant with bright yellow flowers shaped like small cups" [4, p. 153]. More than that, the buttercup [10, p. 447] indicates an innocent and attractive girl in the American linguoculture.
Traditions and beliefs connected with the floronyms furze (variants gorse / whin) are embodied in paroemias: when the furze is in bloom, my love's in tune [6, p. 208]; when the gorse is out of bloom, kissing's out of fashion [8, p. 44]; When whins are out of bloom, kissing's out of fashion [6, p. 329] known since 1847. The second and third sayings serve as a pretext for kissing in any time of the year, as the plant furze is blooming all the year round. The floronym furze is defined: "a bush with thin leaves with sharp points and small yellow flowers that do not fall off in winter. Furze often grows on land that is not used or cared for" [25]. Hence, the analysed floronym has the seme "blooming / flowering" and implicates love.

Arange of stereotyped similes with theresearchedfloronym rough as gorse [10, p. 445]; coarse as Hickling gorse [10, p. 445]; sharp as whins [10, p. 445]; close [secretive] / wick [full of life, animosity] as a whin $[10, \mathrm{p}$. 445] directly testify to the roughness, sharpness, pungency of a plant as well as to the cruelty of man in the figurative meaning. The concept secretiveness is phraseologically verbalised in the final simile. The analysed floronym acquires the association with perspiration within the boundaries of the phraseologism: sweat like a fuz [=furze]-bush on a dewy morning [10, p. 445].

A supplementary synonym of the researched floronym whin (which is of the Scottish origin) is used in the saying Pleaing [pleading] at the law is like fighting through a whin [furze] bush, - The harder the blows, the sairer [sorer] the scarts [scratches] [6, p. 633]; pleaing at the law is like fighting through a whinbushthe harder the blows the sairer the scarts (Sc: 1832) [10, p. 445] for comparison with the system of law proceedings, which was imperfect in the past. The floronym under analysis has the seme "pungency / sharpness" and can be associated with injustice.

The idiom give / take through the whins [10, p. 391] means "to reprimand severely", and come / go through the whins [10, p. 391] - "suffer from hardships." Hence, the researched floronym incorporates the associations with reproach and problems. Besides, the floronym whin can imply something unimportant, namely: inches don't break squares in a load of whins [10, p. 445].

The paroemia of the Scottish origin ye canna gather berries off a whinbush [Sc] [10, p. 445] verbalises the concept greed, because it depicts a miser, who is compared to a thorny plant. According to K. Mizin's observation, "the British community is still dominated by a positive and frugal attitude towards property. At the same time, boundless (reckless, wasteful) generosity is marked by certain reasonable limits, and avarice is condemned as a very shameful phenomenon" [26, p. 268].

The paroemia March wind kindles (wakes) the adder and blooms the thorn (whin) [6, p. 512] contains the analysed floronym, which has the semantic component "to bloom" as well as temporal characteristics.

The PhI that functions in the English language dance barefoot over the fuz [=furze] [10, c. 898] signifies an unmarried person present at the wedding of a younger sibling. Consequently, the phraseologism underlines the importance of marriage, and the components of floronym furze's semantics contribute to this.

The English ironic paroemia When Kingswear was a market town Dartmouth was a furzy down [6, p. 428] verbalizes the envy of one town's inhabitants of the other in rhyme. Semantic components of the researched floronym serve as a basis for verbalisation of the binary oppositions "own - alien" and "better - worse." Many imagery contexts of envy correlate 
with such conceptual oppositions as "own — alien, richness poverty, light — darkness" [27, p. 268]. This universal tendency to idealize one's own, broadly expressed in proverbs and sayings of different languages, is a reflection of human egocentrism [28, p. 219]. It is traditionally considered, that the psychological basis of the analyzed opposition is the axiological contrasting in the archaic consciousness of one's own as positive, safe, wellknown, to alien as negative, dangerous, unknown [29, c. 45].

The floronym patience was paroemiologically verbalized, namely in: Patience is a flower that grows not in every one's garden [8, p. 198]; Let patience grow in your garden always [8, p. 198]; Let patience still in your garden appear [8, p. 612]; an allusion to patience (endurance) was created on account of the pun which is based on the homonymity of these lexemes. Thus, the floronym patience can be associated with endurance.

The colour name lavender $[5$, p. 656] is used for the indication of a pale blue / purple colour with a trace of mauve. It originates from the same name floronym with the denotative meaning: " $a$ plant with sweet-smelling pale purple flowers; its dried flowers used to give sheets, clothes, etc. a pleasant smell" [4, p. 667].

The idiom to lay (lay up) in lavender (sth) [5, p. 656] has the figurative meaning "to save for the future use, to hide something to be used in case of necessity", and it is derived from the initial literal meaning of the phrase "to lay up linen in lavender for the sake of fragrance." An additional figurative meaning of the phraseologism is "to pawn something", whereas to lay (up) in lavender (sb); put away / lay up in lavender [10, p. 753] - "to get sb out of the way or imprison sb", which is a dated idiom. The slangy expression lay out in lavender [16, p. 235] is associated with a quarrel, reprimand. The same $\mathrm{PhI}$ lay out in lavender [US] [10, p. 642] in American English means "to kill in the fit of rage / fury". The PhI of the Irish origin lie in lavender [10, p. 753]; lying in lavender, like Paddy's pig $[10$, p. 279] (literally "to live in comfort") verbalizes the concept comfort, and the semantic components of the researched floronym serve as a basis for that. Therefore, the floronym lavender can bear the connotation of thrift and extremity, be associated with freshness, storage, comfort, pawn and even murder under the sway of passion, as well as death or imprisonment.

There exist such terms as lavender-water [5, p. 656]; lavender oil [25]; oil of lavender [30] in the area of perfumery. The analysed floronym explicates the inherent seme "fragrance."

At the beginning of the 21 st century there appear such idioms with the researched floronym, as: lavender language [14] signifying "words, phrases and the manner of speech, which are inherent of homosexual people" and the phraseologism, that originated at the beginning of the $20^{\text {th }}$ century and is still applicable today: lavender marriage $[3 ; 17]$ - an instance of the marriage of convenience esp. with celebrities, which is aimed at concealing the fact that their sexual orientation is not primarily heterosexual. Therefore, the semantics of the floronym lavender can possess a connotation of homosexuality. According to O. Babeliuk: "Postmodernist conception of globalized man, a cosmopolitan, provides for liberation from the legacy of traditional identity morality and provokes a change of mentality, tolerance of the free choice of identity" [31, p. 5].

The floronym pansy is characterized by the following definition in the English language: "a garden plant with a short stem and broad flat flowers of various bright colours" [4, p. 838]. The derivative colour name pansy / pansy violet [21, p. 80] is used for the denotation of a strong violet colour. In the colloquial speech the floronym pansy [11, p. 975]; pansy boy [21, p. 80] belongs to vulgar lexis and signifies a weak effeminate man / boy; and a dated offensive invective word used for the indication of a homosexual man. Consequently, the researched floronym can be associated with weakness, pretentiousness, effeminacy and homosexuality in the English linguoculture.

The floronym wallflower is defined in the English language as follows: "a garden plant with yellow, orange or red flowers with a sweet smell that appear in late spring" [25]. In the figurative meaning, the analysed floronym can indicate a lady, who remains without a partner at a party [10, p. 784]; a girl, who does not enjoy popularity [21, p. 650]; an inmate, obsessed with escape from prison [10, p. 784]; and in maritime terminology a ship, which has been on a permanent anchor mooring for long [21, p. 651]. The semantic constituents of the floronym under research contribute to phraseological verbalisation of the concept waiting. The PhI Faint at the smell of a wallflower [6, p. 864]; he will faint at the smell of a wallflower [6, p. 238] was used with reference to the inmates in Newgate prison in Dublin, as wallflowers have been planted along the walls there since 1787. The same adage is applicable to an excessively sensitive or cowardly person.

In the English linguoculture, the floronym tulip is associated with something magnificent, colourful, bright, presumably, on account of its colouring. In the figurative meaning, it can be used with reference to a person who is dressed in gaudy tasteless clothes, namely, as in the simile: gaudy as a tulip [10, p. 785]. The English definition of the floronym is as such: "a large, brightly coloured spring flower, like a cup in shape, on a tall stem " [25]. The etymology of the researched floronym is of interest, its name originated at the end of the $16^{\text {th }}$ century from French tulipe, via Turkish from Persian dulband "turban", from the similarity in the shape of the expanded flower and the headdress [25]. The association of flowers with revolutions is widespread at the beginning of the $21^{\text {st }}$ century. So, the phraseo-term in the area of political science a tulip revolution [32]; Тюльпа́нова револю́иія [33, р. 617] denotes the uprising in Kyrgyzstan that took place in early 2005. Flowers have become a universal symbol of peace revolutions [19, p. 30].

Conclusions. Floronym daisy can be used as an aviation, IT and military term component. The researched floronym is combined with the attribute fresh and has the semes "freshness, health, cheerfulness". It is significant, that floronym daisy is associated with spring and has temporal characteristics, as it is this flower that belongs to the first that appear in spring. The analysed floronym can be associated with weather changeability, urination, as well as it can be used as a constituent part of a succession of euphemistic phraseologisms, which verbalise the concept death. In the Scottish common consciousness, the floronym denotes a neatly-dressed person and is associated with cleanliness. Both in the English and Scottish languages, the semantic components of the floronym daisy contribute to phraseological verbalization of the concepts difference, incongruity, commonness, happiness. As a part of slangy expressions the researched floronym is associated with a clever, beautiful, optimistic girl or a prominent, excellent thing.

A considerable part of floronym lotus' associations, among them: a daydreamer, daydreams, laziness, delight, a carefree life in a fairy land of pleasure originate from Greek mythology. As a result of secondary nomination and metaphoric reconsideration 
of meaning, the analysed floronym has a pejorative connotation of drug addiction. The associations of the floronym lotus with a position in Yoga were introduced from Eastern meditation practices into the Western culture, respectively, the lotus flower is a token of tranquillity.

The floronym brier (variants briar and wild rose) in combination with the attributes rough/sharp is used both directly and figuratively, denoting a caustic person and has a dominant seme "pungency". The analysed floronym can be associated with a difficult situation, problems, something unpleasant and cruelty of nature. The variant of the researched floronym wild rose explicates the seme "beauty" and serves as a floral symbol of the America state of Iowa.

One of the standards of yellow colour is attributed to the floronym primrose (variants cowslip / paigle). The floronym under analysis symbolizes youth and is associated with tenderness, fading, death, way of pleasure, enjoyable life, laziness, at the same time the components of its semantics contribute to verbalization of the cause and effect connection "idleness $\rightarrow$ decay". The researched floronym can signify a plain lass, inappropriate garment, and its semantic constituents conduce to phraseological objectivation of the incongruity concept.

The floronym buttercup / жовтещь is associated with freshness, can signify an innocent, attractive girl. Moreover, this floronym serves as a prototype of a bright yellow colour in the English and Ukrainian languages. It is noteworthy, that the floronyms gowan / kingcup / globeflower (купальниця); marigold(s) (нагідки, календула); meadow-bout / kingcup (жовтець бульбовий, калюжниця болотяна); guilde / corn marigold (златоцвіт); ragweed/ragwort (жовтозілля, амброзія) can serve as the standards of yellow colour in the English language; since a range of similes with these floronyms coupled with the constant semantic attribute yellow extend in the native speech over the territory of Scotland, Ireland and the North of England.

A range of beliefs and traditions related to the floronyms furze (variants gorse / whin) function in the English culture. Thus, the analysed floronym has the seme "flourish / blooming", is associated with kisses, love as well as perspiration. The floronym under research is used as a structural constituent of a variety of similes where amalgamated with attributes sharp / rough/coarse it denotes a prickly, pungent, thorny plant, and being transferred to the world of people, signifies the cruelty of human nature. In the Scottish linguoculture, the floronym whin can phraseologically verbalize the concept injustice in the judicial system, denote a miser, have associations with scolding, problems, greed and something unimportant. Semantic components of the floronym furze can serve as a basis for phraseological verbalization of the universal binary oppositions "own - alien" and "better - worse".

Associations of the floronym patience with patience (endurance), was established on account of the pun, which is based on the homonymity of the lexemes.

The floronym lavender can be used as a colour name for the representation of a pale blue colour with a trace of mauve. Being used in the direct meaning, the researched floronym has an inherent explicit seme "aroma, fragrance" within the structure of the PhI. In the figurative meaning, it can be associated with freshness, storage, preservation, pawn, quarrel, reproach, prison, death, and in American English - with murder under the sway of passion. Semantic components of the floronym lavender contribute to actualization of the concept comfort within the boundaries of the $\mathrm{PhI}$ of the Irish origin. The semantics of the researched floronym has the implication of thrift and difficulty. The analysed floronym's meaning is characterized by the connotation of homosexuality, as well as floronym pansy's, which can also be associated with weakness, affectedness, effeminacy in the common consciousness of the Englishmen.

Semantic components of the floronym wallflower serve a basis for phraseological actualization of the concept waiting. The floronym under analysis can signify an unpopular female, as well as a ship that has not been at sea long. Associations of the researched floronym with a sensitive / cowardly person and an inmate obsessed with escape have a long history.

Presumably on account of bright colouring, the floronym tulip serves as a manifestation of something colourful, bright in the English linguoculture, at the same time, its semantic components contribute to phraseological verbalisation of the concept tastelessness.

The research of floronyms' semantics that are phraseologically actualized in the Ukrainian language is to be prospected.

\section{References:}

1. Левченко О. П. Фразеологічна символіка : лінгвокультурологічний аспект : Монографія. Львів : ЛРІДУ НАДУ, 2005. 264 с.

2. Коцюба 3.Г. Рефлексія побутової свідомості в різномовному провербіальному просторі (від універсального до національного) : монографія. Львів : ДП «Видавничий дім «Укрпол», 2010. 472 с.

3. The Free Dictionary by Farlex. Farlex Dictionary of Idioms. 2015. URL: https://idioms.thefreedictionary.com/

4. Oxford Advanced Learner's Dictionary of Current English / 5th ed. / Ed. by J. Crowther. Oxford : Oxford Univ. Press, 1995. 1428 p.

5. Англо-український словник: у 2 т. Близько 120000 слів / уклав М. Балла. Київ : Освіта, 1996. Т. 1. 752 с.

6. The Oxford Dictionary of English Proverbs. 3rd ed. / Ed. by F.P. Wilson. Oxford : Clarendon Press, 1992. 930 p.

7. Дубенко О. Англо-американські прислів'я та приказки : посіб. для студ. та викладачів вищ. навч. закл. Вінниця : Нова Книга, 2004. $416 \mathrm{c}$.

8. The Penguin Dictionary of Proverbs. $2^{\text {nd }}$ ed. / Ed. by R. Fergusson \& J. Law. Penguin Books, 2000. 365 p.

9. Англо-український фразеологічний словник / уклад. К. Баранцев. 3-тє вид., стер. Київ : Т-во «Знання», КОО, 2006. 1056 с.

10. Thesaurus of traditional English metaphors. $2^{\text {nd }}$ ed. / P. Wilkinson. London : Routledge, Taylor \& Francis e-Library, 2006. 2009 p.

11. Longman Dictionary of English Language and Culture. 6th impression. Longman : Pearson Education Ltd, 2003. 1568 p.

12. Pamies-Bertrán A. Grammatical metaphor and functional idiomaticity. Yearbook of Phraseology. 8(1), 2017. pp. 59-94. DOI: 10.1515/phras-2017-0005 URL: https://www.researchgate.net/ publication/322550512_Grammatical_metaphor_and_functional_ idiomaticity

13. Longman Idioms Dictionary. Edinburgh : Longman, 1998. 398 p.

14. Cambridge dictionary. Cambridge University Press, 2020. URL: https://dictionary.cambridge.org/.

15. Merriam-Webster Dictionary. URL: https://www.merriam-webster.com.

16. Словарь американских идиом : 8000 единиц / А. Маккей та ін. Санкт-Петербург : Издательство «Лань», 1997. 464 с.

17. Urban dictionary. URL: https://www.urbandictionary.com/

18. The Facts On File Dictionary of Allusions / by Martin H. Manser New York, 2009. $532 \mathrm{p}$.

19. Чернявська А.В. Фразеологічна об'єктивація колективних уявлень про троянду в українській та англійській мовах. Вчені записки ТНУ імені В. І. Вернадського. Серія : Філологія. Том 30 (69), № 3. Ч. 2. 2019, С. 24-32. 
20. A Dictionary of American Proverbs. Ed. in chief W. Mieder. New York: Oxford University Presss. 1992. $710 \mathrm{p}$.

21. Англо-український словник: у 2 т. Близько 120000 слів / уклав М. Балла. Київ : Освіта, 1996. Т. 2. 712 с.

22. Merriam-Webster's dictionary of allusions / by E. Webber \& M. Feinsilber. Merriam-Webster, Inc. Springfield, Massachusetts, 1999. $594 \mathrm{p}$

23. The Oxford Dictionary of Idioms. $2^{\text {nd }}$ ed. / Ed. by J. Siefring. Oxford : Oxford Univ. Press, 2004. 352 p.

24. Milton J. 'On the Death of a Fair Infant Dying of a Cough' (1673). URL: https://www.azquotes.com/

25. Oxford Learner's Dictionaries. Oxford Advanced Learner's Dictionary. URL: https://www.oxfordlearnersdictionaries.com

26. Мізін К. І., Петров О. О. Зміна ціннісного наповнення концептів Щедрість і Скупість у споріднених і неспоріднених лінгвокультурах : дані лінгвокорпусів. Теоретична $і$ дидактична філологія. 2017. Вип. 25. С. 264-276. URL: http://nbuv.gov.ua/UJRN/ Tidf_2017_25_32.

27. Тищенко О. Концептуалізація емоцій та ціннісних концептів у слов'янських пареміях та фраземах: від совісті до заздрості. Науковий вісник Південноукраӥнського наџіонального педагогічного університету імені К. Д. Уиинського. Лінгвістичні науки. 2019. № 29. С. 248-271. URL: http://nbuv.gov.ua/UJRN/ Nvpupu_2019_29_19.

28. Тищенко О. В. Концептосфера дому у слов'янській пареміології на контрастивному тлі. Сучасні дослідження з іноземної філологіï. 2016. Вип. 14. С. 216-234. URL: http://nbuv.gov.ua/UJRN/ Sdzif_2016_14_35.

29. Коцюба 3.Г. Своє - чуже vs добро - зло : взаємозв'язки опозицій у побутовій свідомості носіїв слов'янських, германських і романських мов (на матеріалі паремій). Наукові пращі. Серія «Філологія. Мовознавство». Вип. 85. Миколаїв : Вид-во ЧдУ ім. Петра Могили, 2009. Т. 98. С. 44-49. URL: http://nbuv.gov.ua/UJRN/ Npchdufm_2009_98_85_11.

30. Collins Online English Dictionary. URL: https://www.collinsdictionary.com

31. Бабелюк О.А., Марчишина А. А. Концепція гендерної ідентичності у постмодерністському тексті : варіації на тему самототожності. Записки з украӥнського мовознавства. 2019. Вип. 26(2). С. 4-11. URL: http://nbuv.gov.ua/UJRN/zukm_2019_26(2)_3.

32. Atulip revolution. The Economist Newspaper Ltd. 2021. issn 0013-0613. 2005. URL: https://www.economist.com/unknown/2005/03/24/atulip-revolution

33. Політологічний енциклопедичний словник / уклад. Л. Герасіна, В. Погрібна, І. Поліщук та ін. ; за ред. М. Требіна. Харків : Право, 2015. $816 \mathrm{c}$
Чернявська А. В. Семантика фразеологічно об'сктивованих флоронімів в англійській мові

Анотація. Статтю присвячено дослідженню семантики флоронімів daisy, lotus, briar, primrose, furze, patience, lavender, pansy, wallflower та tulip у фразеології англійської мови. Встановлено, що досліджуваним флоронімам притаманне як меліоративне, так і пейоративне забарвлення. Проаналізовано низку асоціацій та метафоричне й символічне значення досліджуваних флоронімів. Виокремлено ряд концептів, що зазнали фразеологічної вербалізації за допомогою семантичних складників аналізованих флоронімів.

Встановлено, що флоронім daisy асоціюється з весною, свіжістю, чистотою, а його семантичні компоненти сприяють фразеологічній об'єктивації концептів щзастя, смерть, звичайність, відмінність, невідповідність.

Досліджуваний флоронім lotus може символізувати спокій та асоціюватися з наркоманією. Із грецької міфології походять такі асоціації флороніма, як: фантазер, фантазії, втіха, неробство, безтурботне життя. Дві останні асоціації притаманні й флороніму primrose, який може слугувати еталоном жовтого кольору, символізувати юність й асоціюватися 3 тендітністю, в'яненням, смертю, шляхом насолод, при цьому компоненти його семантики слугують основою для фразеологічної об'єктивації концепту неконгруентності та сприяють вербалізації причинно-наслідкового зв'язку «неробство $\rightarrow$ занепад».

Флоронім brier має інгерентну сему «краса» та може асоціюватися з уїдливістю, проблемами, чимось неприємним. Досліджувані флороніми brier та furze експлікують домінуючу сему «колючість» й мають асоціацію 3 жорстокістю натури. Флоронім fигzе асоціюється з поцілунками й коханням, а компоненти його семантики слугують основою для паремійної вербалізації бінарних опозицій «своє - чуже» та «кращий - гірший».

У переносному значенні флоронім lavender може асоціюватися зі свіжістю, зберіганням, заставою, сваркою, тюрмою, смертю, має конотацію заощадливості, скрути. Семантиці досліджуваного флороніма притаманна конотація гомосексуальності, так само як і флороніма pansy, який може також асоціюватися зі слабкістю, афектованістю. Компоненти семантики флороніма wallflower слугують основою для фразеологічної вербалізації концепту очікування, а флороніма tulip - концепту несмак.

Ключові слова: флоронім, ідіома, паремія, символічне значення, сема, семантика, концепт. 